\title{
ANALISIS PENENTUAN PUSAT-PUSAT PERTUMBUHAN EKONOMI DI KABUPATEN SIMALUNGUN
}

Volume 1 nomor 12

PANDAPOTAN T.P NAINGGOLAN

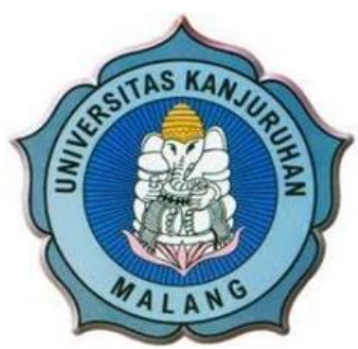

Oleh:

Rosalia Nganur ～(160401050063)

Yeni Marlina Lanem (160401050060)

UNIVERSITAS KANJURUHAN MALANG

FAKULTAS ILMU PENDIDIKAN

PROGRAM STUDI PENDIDIKAN GEOGRAFI

APRIL 2019 


\section{BAB I}

\section{PENDAHULUAN}

\section{A. Latar Belakang}

Pembangunan merupakan masalah utama yang dihadapi oleh negara - negara berkembang. Pada umumnya hampir semua negara berkembang dihadapkan pada permasalahan-permasalahan yang sama yakni kemiskinan, pengangguran, tingkat kesehatan dan pendidikan yang rendah, ketimpangan distribusi pendapatan bahkan kriminalitas yang tinggi (Todaro, 2009). Sama seperti negara yang sedang berkembang pada umumnya, Indonesia juga telah melaksanakan pembangunan mulai dari kemerdekaan hingga sekarang. Gebrakan pembangunan Indonesia dimulai saat diadakannya Rencana Pembangunan Lima Tahun (Repelita) dimana pembangunan tersentralisasi. Akan tetapi, dengan dikeluarkannya UU No. 22 Tahun 1999 pembangunan Indonesia sudah bersifat desentralisasi,dimana pemerintah daerah lebih berperan didalam membangun daerahnya masing-masing. Salah satu solusi yang dapat diambil untuk mempercepat pembangunan suatu daerah adalah pengembangan wilayah dengan menetapkan pusat pertumbuhan.

Ditengah- tengah keterbatasan biaya untuk melaksanakan pembangunan, melalui penetapan pusat pertumbuhan maka pemerintah dapat lebih fokus untuk membangun daerah tersebut yang nantinya daerah pusat pertumbuhan itu akan memberikan efek yang menguntungkan kepada daerah belakangnya. Melalui penetapan pusat pertumbuhan dapat memudahkan pemerintah daerah untuk mempercepat peningkatan kesejahteraan daerahnya. Kabupaten Simalungun adalah kabupaten ketiga terbesar di daerah Sumatera Utara setelah Kabupaten Madina dan Langkat. Kabupaten Simalungun memiliki letak yang strategis karena berada diantara delapan daerah kabupaten, antara lain Kabupaten Serdang Bedagai, Deli Serdang, Karo, Tobasa, Samosir, Asahan, Batu Bara dan Pematangsiantar.

Luas daerah Kabupaten Simalungun 4.386,60 Km2 dan dibagi atas 31 kecamatan. Kecamatan terbesar adalah Raya dengan luas daerah 335,60 Km2 dan kecamatan yang memiliki luas daerah terkecil adalah Haranggaol Horison dengan luas daerah 34,50 Km2. Dengan memiliki wilayah yang sangat luas tentu Kabupaten Simalungun sangat berpotensi untuk membangun perekonomian daerahnya. Tidak hanya itu, selain memiliki wilayah yang luas, Kabupaten Simalungun juga memiliki tanah yan subur sehingga sangat cocok untuk 
pertanian.Selain memiliki letak yang strategi karena diapit oleh 8 kabupaten dan memiliki tanah yang luas dan subur, Kabupaten Simalungun juga memiliki potensi sebagai objek wisata, terutama wisata alam hal ini dikarenakan Kabupaten Simalungun berada di sekitar Danau Toba. Hampir semua kecamatan di Kabupaten Simalungun memiliki daerah tujuan wisata. Enam daerah tujuwan wisata yang sering dikunjungi oleh wisatawan nusantara maupun mancanegara antara lain; Parapat, Karang-Anyer, Museum Simalungun, Rumah Bolon, Haranggaol, Pemandian Alam Sejuk (BPS Simalungun, 2011). Akan tetapi tidak dipungkiri, daerah tujuan wisata yang ada di Kabupaten Simalungun hampir semuanya tidak dikelola dengan baik.

\section{B. Metode Penelitian}

Penelitian ini menggunakan data sekunder yakni data yang diperoleh dari publikasipublikasi suatu lembaga atau instansi. Data diperoleh dari publikasi Biro Pusat Statistik (BPS).

1. Metode analisis

a. Analisis Skalogram Dan Indeks Sentralitas

Analisis Skalogram merupakan suatu alat analisis yang digunakan untuk mengetahui kemampuan suatu daerah dalam rangka memberikan pelayanan kepada masyarakat. Semakin tinggi perkembangan suatu wilayah berarti wilayah tersebut semakin mampu memberikan pelayanan kepada masyarakatnya. Pelayanan yang dimaksud dalam hal ini adalah ketersediaan fasilitas-fasilitas yang ada didaerah itu seperti fasilitas yang berkaitan dengan aktivitas ekonomi, aktivitas sosial dan pemerintahan. Dengan analisis skalogram dapat ditentukan daerah ataupun kecamatan yang dapat dijadikan sebagai pusat pertumbuhan. Kecamatan yang memiliki kelengkapan fasilitas tertinggi dapat ditentukan sebagai pusat pertumbuhan.

b. Analisis Gravitasi

Untuk mengukur daya tarik yang dimiliki oleh suatu daerah atau besarnya interaksi antar daerah dapat dilakukan dengan analisis gravitasi. Analisis gravitasi dilandaskan pada asumsi bahwa interaksi antara dua pusat mempunyai hubungan proporsional langsung dengan "massa" dari pusat-pusat bersangkutan dan mempunyai hubungan proporsional terbalik dengan "jarak" antara pusat-pusat tersebut. Variabel-variabel yang digunakan untuk mengukur "massa" dan "jarak" 
adalah tergantung pada persoalan yang hendak dicapai dan ketersediaan data. Variabel yang dapat mewakili "massa" antara lain; penduduk, kesempatan kerja, pendapatan, pengeluaran, sementara variabel yang dapat mewakili "jarak" dinyatakan dalam ukuran phisik, waktu, harga dan lain-lain. 


\section{BAB II \\ PEMBAHASAN}

\section{A. Hasil dan Pembahasan}

Hasil analisis skalogram yakni analisis yang hanya melihat dari keberadaan fasilitasnya, kecamatan-kecamatan yang ada di Kabupaten Simalungun dikategorikan ke dalam kelompok-kelompok. Dari 30 jenis fasilitas yang didata, jumlah jenis fasilitas tertinggi yang ada didalam satu kecamatan adalah sebanyak 25 jenis fasilitas, sementara yang terendah adalah 13 jenis fasilitas. Dengan memperhitungkan selisih antara jumlah fasilitas tertinggi dan fasilitas terendah, maka kecamatan yang ada di Kabupaten Simalungun dibagi kepada 5 kelompok. Hasil analisis skalogram setiap kecamatan di Kabupaten Simalungun dapat dilihat pada tabel 1.

Kelompok I merupakan kelompok kecamatan dengan tingkat keberadaan fasilitas yang tertinggi yakni kecamatan yang memiliki 23 - 25 jenis fasilitas. Kecamatan yang berada di Kelompok I yakni Kecamatan Bandar, Girsang Simpangan Bolon, Tapian Dolok, Dolok Panribuan, Jorlang Hataran. Jenis fasilitas yang membedakan kelompok I dengan kelompok lainnya adalah keberadaan Rumah Sakit (Bandar, Girsang Simpangan Bolon, Tapian Dolok), Universitas (Bandar, Tapian Dolok), Restoran (Bandar, Girsang Simpangan Bolon, Dolok Panribuan, Jorlang Hataran). Keberadaan rumah sakit dan universitas di Kecamatan Bandar dan Kecamatan Tapian Dolok sangat erat hubungannya dengan jumlah penduduk pada kecamatan tersebut yang banyak. Sedangkan keberadaan Restoran di Kecamatan Bandar, Girsang Simpangan Bolon, Dolok Panribuan dan Jorlang Hataran selain dipengaruhi oleh jumlah penduduk juga dipengaruhi oleh keberadaan Objek Wisata yang ada pada kecamatan tersebut.

Kecamatan yang juga memiliki keberadaan fasilitas yang tinggi adalah kecamatan yang berada di Kelompok II yakni Kecamatan Dolok Batu Nanggar, Pematang Bandar, Bandar Huluan, Tanah Jawa, Bosar Maligas, Raya, Hutabayu Raja, Bandar Masilam, Panei dengan jumlah fasilitas 21-22 jenis. Jenis fasilitas yang membedakan kelompok II yakni : Kantor Pemerintahan, Rumah Sakit, SMA Negeri, SMK Negeri, SMK Swasta, Bank. Dan yang berada di kelompok III yakni dengan ketersediaan fasilitas yang sedang yakni memiliki 1819 jenis fasilitas ada 12 kecamatan yaitu : Siantar, Gunung Malela, Sidamanik, Jawa Maraja Bah Jambi, Hatonduhan, Raya Kahean, Silou Kahean, Dolok Silou, Silimakuta, 
Haranggaol Horison, Panombeian Panei dan Dolok Pardamean. Jenis fasilitas yang menentukan kecamatan yang termasuk kedalam Kelompok III yakni: bank, non bank, SMA Swasta.

Tabel 1.

Kelompok Kecamatan Berdasarkan Ketersediaan Fasilitas Sosial, Ekonomi, Pemerintahan Tahun 2010 Di Kabupaten Simalungun.

\begin{tabular}{|l|l|l|l|}
\hline No & Kecamatan & Jumlah Fasilitas & Kelompok \\
\hline 1 & Bandar & 25 & I \\
\hline 2 & Girsang Sipangan Bolon & 24 & I \\
\hline 3 & Tapian Dolok & 23 & I \\
\hline 4 & Dolok Panribuan & 23 & I \\
\hline 5 & Jorlang Hataran & 23 & I \\
\hline 6 & Dolok Batu Nanggar & 22 & II \\
\hline 7 & Pematang Bandar & 22 & II \\
\hline 8 & Bandar Huluan & 22 & II \\
\hline 9 & Tanah Jawa & 21 & II \\
\hline 10 & Bosar Maligas & 21 & II \\
\hline 11 & Raya & 21 & II \\
\hline 12 & Hutabayu Raja & 21 & II \\
\hline 13 & Bandar Masilam & 21 & II \\
\hline 14 & Panei & 21 & II \\
\hline 15 & Siantar & 20 & III \\
\hline
\end{tabular}




\begin{tabular}{|l|l|l|l|}
\hline 16 & Gunung Malela & 20 & III \\
\hline 17 & Sidamanik & 20 & III \\
\hline 18 & Jawa Maraja Bah Jambi & 20 & III \\
\hline 19 & Hatonduhan & 19 & III \\
\hline 20 & Raya Kahean & 19 & III \\
\hline 21 & Silou Kahean & 19 & III \\
\hline 22 & Dolok Silou & 19 & III \\
\hline 23 & Silimakuta & 19 & III \\
\hline 24 & Haranggaol Horison & 19 & III \\
\hline 25 & Panombeian Panei & 18 & III \\
\hline 26 & Dolok Pardamean & 18 & III \\
\hline 27 & Ujung Padang & 17 & IV \\
\hline 28 & Purba & 17 & IV \\
\hline 29 & Gunung Maligas & 16 & IV \\
\hline 30 & Pematang Sidamanik & 16 & IV \\
\hline 31 & Pematang Silimahuta & 13 & V \\
\hline
\end{tabular}

Kelompok V merupakan kelompok kecamatan yang memiliki tingkat keberadaan fasilitas yang paling rendah, yakni hanya memiliki 13 jenis fasilitas. Kecamatan yang berada di Kelompok V adalah Kecamatan Pematang Silimahuta. Hal ini berhubungan dengan kecamatan Pematang Silimahuta yang baru saja mengalami pemekaran sehingga masih dalam tahap pembenahan. Sementara itu kecamatan yang juga memiliki tingkat ketersediaan fasilitas yang rendah adalah kecamatan yang berada di kelompok IV yaitu Kecamatan Ujung Padang, Purba, Gunung Maligas, Pematang Sidamanik dengan 16 17 jenis fasilitas.

Pada hasil analisis skalogram diatas, dapat dilihat bahwa ada kecamatan yang memiliki jumlah penduduk yang besar akan tetapi tingkat keberagaman fasilitas yang ada pada kecamatan tersebut rendah seperti Kecamatan Siantar dan Ujung Padang. Dan ada juga kecamatan yang memiliki luas penduduk yang kecil tetapi memiliki keberagaman fasilitas yang tinggi seperti Girsang Simpangan Bolon, Jorlang Hataran 
dan Dolok Panribuan. Meskipun demikian, untuk menentukan kecamatan sebagai pusat pertumbuhan tidak cukup hanya melihat keberagaman fasilitasnya saja, tetapi juga mempertimbangkan frekuensi setiap jenis fasilitas tersebut. Tingkat frekuensi fasilitas pada suatu kecamatan mempengaruhi indeks sentralitas kecamatan tersebut. Semakin tinggi frekuensinya maka akan semakin besar nilai sentralitasnya. 


\section{BAB II}

\section{PENUTUP}

\section{A. Kesimpulan}

Berdasarkan data-data yang telah dihimpun, kemudian dianalisis dengan metode analisis yang telah disebutkan sebelumnya, maka dari penelitian yang dilakukan dapat dihasilkan kesimpulan sebagai berikut ini :

1. Berdasarkan hasil analisis skalogram dan indeks sentralitas yang dilakukan dengan menggunakan 30 jenis fasilitas yang dijadikan sebagai indikator terdapat 5 kecamatan yang ditetapkan sebagai kecamatan pusat pertumbuhan yaitu : Kecamatan Siantar, Bandar, Tanah Jawa, Raya dan Bosar Maligas. Kelima kecamatan tersebut memiliki nilai sentralitas yang lebih tinggi dari kecamatan lainnya.

2. Berdasarkan hasil analisis gravitasi menunjukkan bahwa kecamatan pusat pertumbuhan Siantar memiliki hubungan interaksi yang paling kuat dengan Kecamatan Gunung Malela sebagai wilayah hinterlandnya. Kecamatan pusat pertumbuhan Bandar memiliki hubungan interaksi yang paling kuat dengan Kecamatan Pematang Bandar. Kecamatan Tanah Jawa sebagai kecamatan pusat pertumbuhan memiliki hubungan interaksi yang paling kuat dengan Kecamatan Hatonduhan. Kecamatan pusat pertumbuhan selanjutnya yakni Kecamatan Raya memiliki interaksi yang paling kuat dengan Kecamatan Panei sebagai kecamatan hinterlandnya. Dan kecamatan pusat pertumbuhan Bosar Maligas memiliki hubungan interaksi yang paling kuat dengan Kecamatan Bandar. Selain hubungan interaksi antara kecamatan pusat pertumbuhan dengan wilayah hinterlandnya, terdapat juga intraksi sesama kecamatan pusat pertumbuhan. Kecamatan pusat pertumbuhan yang memiliki hubungan interaksi dengan sesama kecamatan pusat pertumbuhan yaitu Kecamatan Tanah Jawa dengan Siantar dan Kecamatan Bandar dengan Bosar Maligas. 


\section{DAFTAR PUSTAKA}

Daldjoeni N, 1998. Geografi Kota dan Desa. Penerbit ITB, Bandung.

Ermawati, 2010. “Analisis Pusat Pertumbuhan Ekonomi Pada Tingkat Kecamatan Di

Kabupaten Karanganyar Provinsi Jawa Tengah”. Skripsi, Fakultas Ekonomi.

Universitas Sebelas Maret Surakarta : Surakarta

Wahyudi Haryono, 2004.” Kota Gombong Sebagai Pusat Pertumbuhan Kabupaten

Kebumen”. Thesis, Pasca Sarjana. Universitas Diponegoro : Semarang

Sasya Danastri, 2011. “Analisis Penetapan Pusat-Pusat Pertumbuhan Baru Di Kecamatan

Harjamukti, Cirebon Selatan”. Skripsi, Fakultas Ekonomi. Universitas

Diponegoro : Semarang 